\title{
KESULITAN MEMBACA PADA ANAK PENDERITA DISLEKSIA
}

\section{Sa'dulloh Muzammil}

IAIN Pontianak

odwianna@gmail.com

\begin{abstract}
Setiap anak dilahirkan dengan bakat tersediri, tidak terkecuali anak yang menyandang disleksia. Mereka terlahir dengan kesulitan belajar, namun pada umumnya mereka adalah anak yang cerdas. Sejatinya yang mereka perlukan adalah treatment yang sesuai untuk mengatasi kesulitan belajar yang dialami. Salah satu kesulitan yang sering muncul adalah kesulitan dalam kegiatan membaca yang merupakan salah satu skill dalam berbahasa. Kesulitan tersebut dapat mempengaruhi anak dalam memahami informasi dan pengetahuan terkini karena mayoritas kegitan belajar melibatkan aktivitas membaca. Untuk mengatasi masalah tersebut, orang tua dan guru sepatutnya bersabar dalam melatih serta secara simultan memotivasi si penderita untuk terus membaca. Instruksi yang jelas dan dorongan yang memadai memungkinkan anak mampu mewujudkan cita-citanya di kemudian hari.
\end{abstract}

Kata kunci

Disleksia, Kesulitan Membaca, Instruksi yang Jelas, Motivasi yang Memadai.

\section{PENDAHULUAN}

Membaca adalah salah satu keterampilanberbahasa, baik bahasa ibu, bahasa kedua maupun bahasa asing. Seorang peserta didik harus menguasai keterampilan tersebut untuk menyerap ilmu pengetahuan dan informasi baru yang bermafaat.Akan tetapi, yang menjadi masalah adalah apabilaadapeserta didik yang mengalami kesulitan ketika terlibat dalam kegiatan tersebut.Realitas menunjukkan bahwa kesulitan membaca merupakan masalah yang paling banyak terjadi pada masa kanak-kanak.Lebih dari 50\% anak-anak memiliki kesulitan dalam belajar membaca sehingga berdampak pada prestasi akademik anak tersebut di sekolah. Diperkirakan 90\% anak akan mengalami masalah di bidang akademik jika anak tersebut mengalami 
kesulitan dalam belajar membaca (Bender\& Crane, 1999). Berdasarkan fakta dari PISA 2001, sekitar 75,6\% siswa berusia 15 tahun pada jenjang pendidikan sekolah menengah di Indonesia memiliki tingkat kemampuan membaca terendah secara internasional.

Aktivitas membaca dan menulis adalah kemampuan dasar yang wajib dikuasai oleh anak usia sekolah dasar (SD). Hal ini karena aktivitas belajar pada anak dimulai dari kegiatan membaca sehingga dalam proses pembelajaran mereka akan mendapatkan banyak informasi penting yang berguna bagi kehidupan mereka di masa datang. Oleh karena itu, sekolah sebagai lembaga formal perlu menciptakan metode pembelajaran dan bimbingan yang khusus dan lebih kreatif untuk meningkatkan kemampuan dan keterampilan bagi siswa yang memiliki kesulitan dalam proses belajar membaca dan menulis.

Fenomena kesulitan dalam membaca sangat menyedihkan sekali jika dialami oleh anak penderita disleksia.Sekitar 5-17\% penderita disleksia di dunia terjadi pada anak usia sekolah dan lebih parahnya lagi 50-100\% penderita disleksia tidak hanya sulit membaca, tetapi mereka juga akan mengalami kesulitan di bidang matematis (Beacham \& James,2006).

Disleksia berasal dari bahasa Yunani, yaitu "Dys" yang berarti kesulitan dan "Lexis" yang berarti kata-kata (Auryn, 2007). Dengan kata lain, disleksia adalah semacam disabilitas yang lazim dialami anak-anak yang umumnya mengalami kesulitan dalam belajar membaca, menulis, atau mengeja kata-kata (Learning Disability = LD) (Menkes, dkk, 2005).Menurut Swantantika (2015), penderita disleksia mampu melihat kata-kata yang tertulis dalam buku, tetapi otaknya tidak mampu menerjemahkan apa yang terlihat. Mereka sulit untuk mengerti dan memahami pelajaran yang disampaikan baik secara audio maupun visual. 
Dapat disimpulkan bahwa disleksia merupakan suatu gangguan belajar berupa kesulitan dalam membaca dan memahami kata-kata atau bahasa.Selain itu, penderita disleksia juga mengalami kesulitan dalam memahami huruf-huruf dalam alfabet, kesulitan memahami berbagai macam warna, kesulitan dalam berbicara, mendengarkan irama atau suara, arah dan simbol yang mereka lihat.Penyebab disleksia merupakan faktor bawaan yang diturunkan oleh orang tua penderita gangguan disleksia. Data menunjukkan bahwa 23-65 \% orang tua yang mengidap disleksia besar kemungkinan akan menurunkan gangguan tersebut kepada anaknya (Dewi, 2010).

Disamping mengalami kesulitan dalam membaca, penderita disleksia juga mengalami kesulitan dalam menulis dan mempelajari suatu bahasa. Hal ini diperkuat oleh pendapat Sally \& Bennet (2006) bahwa dalam mempelajari bahasa, penderita disleksia akan menggunakan bagian otaknya yang lain yang berbeda dengan individu lain pada umumnya sehingga mereka akan melakukan hal yang berbeda ketika memproses/menerjemahkan bahasa.Mengingat pentingnya kemampuan membaca pada anak, termasuk bagi penderita disleksia, maka perlu adanya dorongan atau motivasi untuk belajar membaca sehingga dapat meningkatkan kemampuan akademik mereka disekolah.

\section{PEMBAHASAN}

\section{Pengertian Diseleksia}

Disleksia merupakan suatu kelainan neurobiologis yang ditandai dengan kesulitan dalam mengenali dan memahami kata-kata dengan tepat dalam pengejaan tulisan dan pengkodean suatu simbol. Hal ini terjadi karena otak lambat atau sulit memproses masukan (input) sehingga mempengaruhi daerah kognitif pada otak seperti daya ingat, pengendalian gerak dan 
koordinasi, serta kemampuan pengaturan waktu yang berbeda dengan anakanak pada umumnya (Dewi, 2010).

Terdapat perbedaan anatomi antara otak anak penderita disleksia dengan anak pada umumnya, yaitu pada otak bagian samping (kiri) dan bagian belakang (temporal-pariental-oksipital). Dengan menggunakan alat pemeriksaan functional magnetic resonance imaging, yaitu alat yang berfungsi untuk memeriksa otak didapatkan hasil bahwa pada saat dilakukan aktivitas membaca pada anak penderita disleksia dan anak normal menunjukkan bahwa aktivitas otak pada anak disleksia sangat berbeda dengan anak normal, terutama kaitannya dalam hal memproses masukan (input) huruf/kata yang telah dibaca kemudian diterjemahkan menjadi suatu makna (Dewi, 2010).

\section{Faktor Penyebab Munculnya Disleksia}

Valentina (2014) membagi jenis disleksia berdasarnya penyebabnya, yaitu disleksia karena penyebab bawaan dan disleksia bukan karena penyebab bawaan. Kedua jenis diklesia tersebut diuraikan berikut ini.

(a). Disleksia karena penyebab bawaan.

Disleksia jenis ini muncul pada seseorang sejak lahir atau secara genetik. Hal ini terjadi karena si penderita mewarisi stuktur dan fungsi otak yang tidak normal atau rusak yang dialami sejak dalam kandungan atau setelah persalinan karena kurangnya asupan nutrisi selama kehamilan; ibu yang menderita depresi dan mengonsumsi minuman keras dan obat-obatan terlarang; kekurangan oksigen, dan lain sebagainya.

Disleksia tipe ini disebut juga sebagai developmental dyslexsia.Beberapa penelitian menyebutkan bahwa penyakit ini berkaitan dengan disfungsi daerah abu-abu pada otak.Disfungsi tersebut berhubungan dengan 
perubahan konektivitas di area fonologis (membaca). Beberapa tanda awal disleksia bawaan yaitulambat berbicara, artikulasi tidak jelas dan terbalikbalik, kesulitan mempelajari bentuk dan bunyi huruf-huruf, bingung antara konsep ruang dan waktu, serta kesulitan mencerna instruksi verbal, cepat, dan berurutan. Pada usia sekolah, umumnya penderita disleksia dapat mengalami kesulitan menggabungkan huruf menjadi kata, kesulitan membaca, kesulitan memegang alat tulis dengan baik, dan kesulitan dalam menerima benda yang diberikan (Marjuki, 2012)

(b). Disleksia bukan karena penyebab bawaan.

Disleksia bukan karena penyebab bawaan umumnya terjadi karena adanya trauma/benturan di kepala yang bisa disebabkan oleh kecelakaan yang berakibat rusaknya bagian otak tertentu, khususnya bagian yang mengendalikan/mengatur kemampuan berbahasa atau penglihatan seseorang.

Sementara itu, berdasarkan penelitian yang dilakukan oleh Hidayah (2012), faktor penyebab kesulitan membaca dan menulis pada siswa penderita disleksia adalah sebagai berikut.

(c). Disfungsi sistem saraf

Terdapat kelainan sistem saraf yang dialami siswa pada tubuh sebelah kanan. Hal ini disebabkan siswa tersebut mengalami kejang-kejang pada usia tiga bulan sehingga ia mengalami kelainan sistem motorik pada mata dan tangannya. 
(d). Perkembangan yang lambat dan kekurangan gizi/nutrisi

Siswa yang menderita disleksia mengalami keterlambatan dalam berbicara dan baru dapat berbicara setelah berusia tiga tahun.Ini didukung juga oleh faktor kekuragan nutrisi pada siswa tersebut.

(e). Daya ingat lemah dan memori jangka pendek lambat

Siswa yang mengalami disleksia akan kesulitan mamahami perintah yang panjang dalam satu waktu yang pendek. Kemungkinan besar mereka tidak mampu melakukan seluruh perintah dengan sempurna karena mereka tidak mampu mengingat seluruh perintah tersebut.

(f). Pengaruh lingkungan keluarga

Dalam hal ini, lingkungan keluarga tidak mendukung aktivitas siswa dalam belajar, terutama dalam melatih kemampuan membaca dan menulis.Selain itu, keadaan keluarga tidak harmonis dan fasilitas serta sarana pembelajaran tidak memadai.

(g). Kurang matang fisik, sosial, dan emosional

Dalam bergaul dengan teman-temannya disekolah, siswa penderita disleksia ingin menang sendiri dan sangat sensitif karena seringkali ia mendapat ejekan dari teman-temannya jika ia tidak dapat mengerjakan/menjawab soal yang diberikan oleh guru kepadanya. Ia pun sering merasa tidak percaya diri dengan teman-temannya di kelas. Biasanya siswa tersebut sering terdiam dan melamun serta menyendiri di saat melakukan aktivitas belajar.Namun demikian, ia memiliki daya tanggap yang tinggi dan pemahaman yang baik di luar kemampuan teman-temannya. 


\section{Masalah-Masalah Umum yang Dihadapi Penderita Disleksia}

Selain mengalami kesulitan dalam membaca, secara lebih spesifik, Dewi (2010) menyatakan bahwa penderita diseleksia biasanya mengalami masalah-masalah sebagai berikut.

(a). Masalah fonologi

Masalah fonologi berkaitan dengan huruf dan bunyi. Anakanakpengidap disleksia cenderung sulit membedakan kata-kata yang bunyinya mirip seperti bunyi "kampus" dengan "kamus" atau antara kata yang memiliki kata depan yang sama seperti "lima belas" dengan kata "lima puluh". Selain itu, berdasarkan pengamatan terhadap anak si penulis sendiri yang juga merupakan pengidap diseleksia; si anak keliru menyebutkan kata "semangka" menjadi "rasamangka". Kesulitan ini tidak terjadi karena permasalahan pada pendengaran, tetapi berkaitan dengan pengolahan input di dalam otak.

(b). Masalah mengingat perkataan

Mayoritas anak penderita disleksia memiliki intelegensi normal atau bahkan di atas rata-rata, tetapimereka mempunyai masalah dalam hal mengingat perkataan.Biasanya mereka dapat menjelaskan suatu cerita, tetpi tidak dapat mengingat jawaban untuk pertanyaan sederhana. Bahkan, boleh jadi mereka sulit mengingat nama teman-teman mereka. Misalnya, alih-alih menyebutkan nama temannya, mereka lebih memilih mengatakan "teman sekolahku" atau "teman mengajiku". 
(c). Masalah penyusunan yang sistematis/sekuensial

Para penderita disleksia sulit menyusun sesuatu secara berurutan, seperti susunan hari dalam seminggu dan bulan dalam setahun serta susunan huruf dan angka.Mereka sering lupa urutan aktivitas yang harus dilakukan berdasarkan rencana yang sudah disusun sebelumnya, seperti lupa setelah sekolah harus pulang ke rumah dulu atau langsung ke tempat latihan berenang, meskipun orang tuanya sudah mengigatkan mereka atau mereka sudah membuat catatan agenda kegiatan tersebut. Mereka juga bingung ketika harus memperkirakan jangka waktu; mereka sulit memahami instruksi seperti berikut ini: "waktu untuk mengerjakan ujian ini adalah 60 menit. Ujian dimulai pukul 09 pagi dan 15 menit sebelum waktu ujian berakhir guru akan mengetuk meja satu kali’.Bukan hanya itu, terkadang mereka juga bingung dengan perhitungan sederhana untuk jumlah uang, misalnya mereka tidak benar-benar yakin apakan uang mereka cukup untuk membeli sepotong jajanan atau tidak.

(d). Masalah ingatan jangka pendek

Anak disleksia sulit memahami instruksi yang panjang dalam waktu yang pendek.Misalnya seorang ayah menyuruh anaknya untuk membeli empat bungkus nasi goreng, masing-masing satu bungkus tidak pedas, satu bungkus pedas tanpa petsin, satu bungkus sedang, dan satu bungkus yang terakhir sedang tanpa kecap.Kemungkinan besar adalah anak tersebut melaksanakan instruksi secara tidak sempurna sebab dia sulit mengigat seluruh perkataan ayahnya. 
(e). Masalah pemahaman sintaks

Penderita disleksia sering kesulitan dalam memahami gramatika bahasa, terutama ketika memahami dua atau lebih bahasa yang berbeda dalam waktu yang bersamaan.Si penderita akan kebingungan memahami tata bahasa pada bahasa kedua atau bahasa asing yang sedang dipelajarinya. Misalnya, dalam bahasa Indonesia dikenal susunan diterangkan-menerangkan (DM), seperti contoh seorang gadis cantik, sedangkan dalam bahasa Inggris susunannya adalah sebaliknya, yaitu menerangkan-diterangkan (MD) seperti contoh a beautiful girl.

\section{Kesulitan Berbicara, Membaca, dan MenulisPada Penderita Disleksia.}

Menurut Sally (2003), kesulitan membaca pada penderita disleksia usia sekolah dasar ditandai oleh beberapa hal, yaitu (1) keterampilan dan kemampuan membaca yang sangat lambat, (2) kesulitan membaca, melafalkan, dan menguasai kata-kata baru, (3) kesulitan membaca kata-kata “di", "pada", dan "ke", ( 4) kesulitan dalam mengeja karena sulit dalam membedakan antara huruf $\mathrm{b}$ dengan $\mathrm{d}, \mathrm{m}$ dengan $\mathrm{n}$, dan sebagainya, (5) kesulitan dalam menulis (hasil tulisan tangan tidak rapi/berantakan), dan (6) kesulitan dalam mempelajari bahasa asing. Di samping itu, penderita disleksia mempunyai masalah dalam kemampuan berbicara seperti (1) salah dalam pelafalan kata-kata yang panjang, (2) bicara tidak lancar, dan (3) menggunakan kata-kata yang tidak tepat dalam berkomunikasi.Sementara itu, dalam hal menulis, pengidap disleksia biasanya lamban dalam menulis, baik saat didikte maupun menyalin tulisan. Mereka juga sulit membedakan huruf konsonan dan huruf vokal serta sulit mempelajari huruf tegak bersambung (Suci, 2015). 
Meskipun penderita disleksia mengalami berbagai masalah dalam belajar sebagaimana disebutkan di atas, bukan berarti mereka memiliki tingkat intelejensi/kecerdasan yang lebih rendah dibandingkan dengan manusia pada umumnya.Bahkan, kebanyakan penderita disleksia memiliki IQ di atas ratarata.Mereka mempunyai pikiran dan wawasan yang lebih baik dan berbeda dengan manusia pada umumnya (out of the box) (Suci, 2015).

Selain itu, penderita disleksia memiliki sistem saraf otak yang berbeda dengan individu pada umumnya karena mereka memiliki bagian otak kanan yang lebih besar dibandingkan otak kirinya. Karena itu, mereka mempunyai kelebihan dan kekurangan yang perbedaannya begitu jelas terlihat. Ukuran otak kanan yang lebih besar tersebut merupakan kekuatan atau keunggulan bagi mereka dalam hal kreativitas dan intuisi yang jauh melebihi individu lain pada umumnya.

Beberapa orang sukses di dunia merupakan penderita disleksia. Mereka itu, antara lain adalah penulis novel Agatha Christie, vokalis band terkenal "Maron 5" Levine, aktor Hollywood, Tom Cruise, mantan Perdana Menteri Inggris, Winston Churchill, pencipta tokoh kartun Mickey Mouse, Walt Disney, Steve Jobs, Pendiri Microsoft, Bill Gate, penemu listrik, Thomas Alfa Edison, fisikawan jenius, Albert Einstein, dan petinju legendaris, Muhammad Ali (Valentina, 2014).

Masih banyak lagi nama popular lain yang menderita disleksia. Saat ini bahkan penderita disleksia sangat diminati dan dicari untuk dijadikan anggota badan antariksa Amerika (NASA) karena lebih dari $50 \%$ anggota NASA merupakan penderita disleksia. Hal ini terjadi bukan tanpa alasan. Pertimbangannya adalah penderita disleksia memiliki keunggulan dalam memecahkan/menyelesaikan masalah dengan sangat luar biasa melalui ide-ide cemerlang yang muncul dalam pemikiran mereka yang jarang terpikir dan 
terlintas di benak manusia pada umumnya (Valentina, 2014).Namun, kondisi tersebut harus diwaspadai. Tidak jarang penderita disleksia akan mengalami kehancuran atau kegagalan dalam kehidupannya karena mereka tidak mengerti bagaimana cara mengatasi gangguan tersebut. Selain itu, terkadang mereka tidak menyadari bahwa mereka mengidap gangguan tersebut. Sebaliknya, jika dapat ditangani dengan cara yang tepat, bakat tertentu yang terdapat pada mereka akan menghasilkan keberhasilan yang luar biasa dalam pekerjaannya.

\section{Solusi dan Strategi Dalam Membantu Penderita Disleksia}

Melihat begitu kompleknya masalah yang dialami penderita disleksia pada siswa di sekolah, sangat diperlukan peran guru sebagai pendidik untuk membantu dan membimbing siswa dalam kegiatan membaca, antara lain (a) memberikan kesempatan kepada siswa untuk mempratikkan kegiatan membaca, (b) memberikan perintah secara sistematis yang dapat dipahaminya dengan cara-cara yang tepat dalam mengeja kata ataupun membaca sebuah teks, (c) perintah yang tegas dalam strategi pembelajaran fonemik (Schneider, 2000).

Seorang dokter spesialis dan pemerhati anak di Indigrow Child Development Center, dr. Kristiantini Dewi, Sp. A. menyarankan langkahlangkah dalam memperlakukan anak dengan disleksia sebagaimana berikut:

(a). Ciptakan komunikasi dan pemahaman yang sama antara orang tua dan guru mengenai anak penderita disleksia.

(b). Minta anakpenderita disleksia untuk duduk di barisan paling depan di kelas. 
(c). Guru senantiasa mengawasi/mendampingi saat anak diberikan tugas, misalnya guru meminta dibuka halaman 15 , pastikan anak tidak tertukar dengan membuka halaman lain, misalnya halaman 50.

(d). Guru dapat memberikan toleransi pada anak disleksia saat menyalin soal di papan tulis sehingga mereka mempunyai waktu lebih banyak untuk menyiapkan latihan (guru dapat memberikan soal dalam bentuk tertulis di kertas).

(e). Anak disleksia yang sudah menunjukkan usaha keras untuk berlatih dan belajar harus diberikan penghargaan yang sesuai dan proses belajarnya perlu diselingi dengan waktu istirahat yang cukup.

(f). Latih anak disleksia untuk menulis sambung sambil memperhatikan cara duduk dan memegang pensilnya. Tulisan sambung memudahkan siswa membedakan antara huruf yang hampir sama misalnya 'b' dengan 'd'. Siswa harus diperlihatkan terlebih dahulu cara menulis huruf sambung karena kemahiran tersebut tidak dapat diperoleh begitu saja. Pembentukan huruf yang betul sangatlah penting dan siswa harus dilatih menulis huruf huruf yang hampir sama berulangkali. Misalnya, hurufhuruf dengan bentuk bulat: "g, $c, o, d, a, s, q$ ", bentuk zig zag: " $k, v, x$, z", bentuk linear:"j, $t, l, u, y, j$, bentuk hampir serupa:"r, $n, m, b$ ".

(g). Pada aspek emosi, anak disleksia dapat menjadi sangat sensitif, terutama jika mereka merasa bahwa mereka berbeda dibanding teman-temannya dan mendapat perlakuan yang berbeda dari gurunya. Lebih buruk lagi jika prestasi akademis mereka menjadi demikian buruk akibat "perbedaan” yang dimilikinya tersebut. Kondisi ini akan membawa anak menjadi individu dengan "self-esteem" yang rendah dan tidak percaya diri. Jika hal ini tidak segera diatasi akan terus bertambah parah dan menyulitkan proses terapi selanjutnya. Orang tua dan guru seyogyanya 
adalah orang-orang terdekat yang dapat membangkitkan semangatnya, memberikan motivasi dan mendukung setiap langkah usaha yang diperlihatkan anak disleksia. Jangan sekali-kali membandingkan anak disleksia dengan temannya, atau dengan saudaranya yang tidak disleksia (Dewi, 2010).

\section{PENUTUP}

Setiap anak mempunyai kelebihan dan kekurangan masing-masing, tidak terkecuali dengan anak-anak penderita disleksia yang mengalami kesulitan belajar (learning difficulty). Meskipun demikian, penderita disleksia memiliki kelebihankarena pada umumnya mereka dilahirkan dengan kecerdasaan atau IQ di atas rata-rata.Oleh sebab itu, orang tua sepatutnya bersyukur bilamana dianugerahi anak yang mengidap disleksia, bukan malah bersedih dan frustrasi. Begitu juga guru yang berkesempatan mendidik anakanak dengan masalah belajar tersebut, semestinya bangga karena sejatinya anak tersebut merupakan permata atau bahkan berlian yang apabila diasah akan terlihat kemilaunya.

Adalah sebuah tantangan untuk orang tua dan guru dalam membantu dan memfasilitasi anak-anak tersebut. Yang perlu dilakukan adalah mengenali terlebih dahulu tanda-tanda anak pengidap disleksia sehingga anak-anak tersebut mendapat perlakuan yang sesuai dengan kebutuhan mereka sehingga nanti mereka menjadi orang-orang yang luar biasa sepertiAlbert Einstein, seorang fisikawan jenius. Albert Einstein yang merupakan penyandang disleksia berpesan sebagai berikut: Everybody is a genius. But if you judge a fish by its ability to climb a tree, it will live its whole life believing that it is stupid (http://www.RumputLiar-AdaApadenganDisleksia.html, 20 Maret 2017). 


\section{DAFTAR PUSTAKA}

Auryn,V. (2007). How to Create Smart Kids. Diterjemahkan Oleh: Wahyu Santoso.Jakarta: Kata Hati.

Beacham, Nigel A. \& James L. Alty.(2006). An investigation into the effects that digital media can have on the learning outcomes of individuals who bave dyslexia. Computers \& Education. 47 74-93

Bender, W. N. \& Crane, M. K. (1999). Stress, Depression, and Suicide among Students with learning disabilities: Assessing The Risk. Learning Disability Quarterly, 22, 143-156.

Dewi, Kristiantini. (2010). Disleksia (Si Pintar yang Sulit Membaca). Diakse 19 Pebruari 2017 dari http://indigrowchilddevelopmentcenter.html/DISLEKSIA/pintartapi-sulit-membaca/

Hidayah, Rifa. (2012). Kemampuan Baca-Tulis Siswa Disleksia. Skipsi Tidak Diterbitkan. Universitas Islam Negeri Maulana Malik Ibrahim Malang.

Marjuki, Andriyansyah. (2012). Kesamaan Einstein dan Tom Cruise: Disleksia. Diakses 3 Maret 2017 dari http://www.KOMPASIANA.com/KesamaanEinsteindanTomCruis e DISLEKSIA/

Menkes, J.H, H.B. Sarnat B.L. Maria. (2005). Learning disabilities, dalam J.H. Menkes, HB. Sarnat (penyunting).Child Neurology, Edisi ke-7. Lippincott Williams and Wilkins: Philadelphia.

Suci P, Norma. (2015). Disleksia? Sulit Membaca Tapi Tetap Istimewa. Diakses 17 Januari 2017 dari http://pijarpsikologi.org/disleksis-sulitmembaca-tapi-tetap-istimewa/.

Sally,Shaywitz. (2003). Overcoming dyslexia. Ney York: Alfred A Knopf.

Sally, Shaywitz\& Bennett. (2006). Dyslexia, dalam: KF. Swaiman, S. Ashwal, DM. Ferreier (penyunting).Pediatric Neurology Principles And Practice.1(4). Mosby: Philadelphia. 
Schneider, W. (2000).Training Phonological Skills. Dyslexia in Chinese: Clues from Cognitive Neuroxychology. 92(2). 284-295.

Swastantika, D. (2015). Disleksia - Penyebab, Gejala, dan Cara Menanganinya. Diakses 17 Januari 2017 dari http://id.theasianparent.com/ketahui-tentang-disleksia/2/

Valentina, Vica. (2014). Scotopic Sensitivity Syndrome (Irlen Syndrome). Diakses $\quad 10 \quad$ Maret $2017 \quad$ dari http://www.ScotopicSensitivitySyndrome(IrlenSyndrome).html/ 